\title{
実機検査データによる疲労寿命のベイズ推定
}

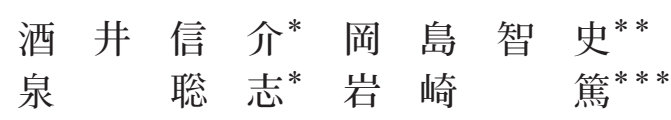

\section{Bayesian Inference of Fatigue Life Estimated by Inspection Data}

by

\author{
Shinsuke Sakai ${ }^{*}$, Satoshi OkaIIma ${ }^{* *}$, Satoshi Izumi ${ }^{*}$ and Atsushi IwaSaKI ${ }^{* * *}$
}

\begin{abstract}
Recently, importance of risk assessment has greatly increased. However, data of failure probability do not exist sufficiently in our country. Therefore, the method to obtain the probability of failure from inspection data is required. This paper investigates the method to estimate the mother distribution of failure life of structures by inspection data using Bayesian inference. Though Bayesian inference is widely said to be effective for the estimation from small samples, the effectiveness greatly depends on the initial setting of a prior distribution. In this paper, the applicability of Bayesian inference is examined first. For this purpose, Bayesian inference is applied for estimating fatigue life by the inspection data of boiler parts. Next, influence of the initial prior distribution on the results is studied systematically by giving variation to mother parameters. Weibull distribution is assumed for the fatigue life distribution and the investigation is made on scale parameter and shape one. In order to assist the inspection planning, the estimations of MTBF and hazard rate are also investigated. As the result, the relation between the initial prior distribution and the effective range by Bayesian inference is clarified.
\end{abstract}

Key words : Bayesian inference, Weibull distribution, Fatigue life estimation, Mean time between failure, Hazard rate, Inspection planning, Risk assessment

\section{1 緒}

\section{言}

機器の検査へのリスクベース工学の導入の必要性が高 まっている.1), 2)リスクは, 破損確率と影響度との積とし て評価される。破損確率データとしては米国石油協会の API5813) が広く認知されているが, 機械構造物の評価に おいては，我が国の実情に即したデータを用いることが 必要である。ところが, 我が国ではこれまでは, リスク 評価への適用を意識した多様な機器に対する破損確率お よび寿命分布データの系統的な整備が行われてこなかっ たために，破損確率評価に資するような情報が十分に得 られないという問題が存在する。このような状況を改善 するための一つの方策として，本論文では，小標本のサ ンプルデータから, 効率よく母集団を推定することに応 用されているべイズ推定 ${ }^{4)}$, 5)を検査データに適用する方 法について検討する。我が国では，検査記録は数多く存 在するものの，必ずしもそのデータが破損確率推定に利 用できる情報を含んでいるとは限らない。このため一般 に, 既存のデータもしくは今後の検査データから機器の 破損確率を推定する際に, 十分な量のデータが利用でき ない，その一方で，類似機器に共通にあてはまる沉用の データベースは入手が比較的容易であることも多い。こ のような場合に, 類似機器に共通するデータベースの情 報を事前の確率分布として推定に利用することの出来る ベイズ推定を利用することが，極めて有効である。ただ
し，ベイズ推定の有効性は，事前分布の与え方や，得ら れるデータ量などにも依存するため，その適用性につい て検討が必要である。本論文においては，ボイラ部品の 検査データに対してベイズ推定を行い，寿命分布の母数 推定を行い, 有効性を検証するとともに, シミュレーショ ンを通じて, 事前分布と推定精度との関係を系統的に調 査する。

\section{$2 \cdot 1$ モデルと推定手法}

\section{2 寿 命推 定手法}

現場での検査データは，検査回数と損傷の有無という 形で保存される場合が多い。このような検査データを損 傷確率評価に有効利用するために, 機器の寿命および検 査を, 次のようにモデル化した。対象とする機械構造物 に対し, 装置の起動および停止に伴って疲労損傷が累積 し，き裂が発生する。このき裂が検査によって検出され うる長さに到達するまでの時間を寿命と定義した。例え ば，発電プラントの起動停止に伴う熱サイクルによる低 サイクル疲労がこのモデルに該当する。検査によって， 寿命に至った機器のき裂は見落とされることなく発見さ れ，その時点で新品に交換されるものとした．検査記録 から寿命分布を推定し, 損傷確率評価に結びつけること を考える. 疲労き裂発生寿命の分布として下記の二母数 ワイブル分布を仮定した。

\footnotetext{
$\dagger \quad$ 原稿受理 平成 16 年 4 月 12 日 Received Apr. 12, 2004

* 正 会員 東京大学大学院工学系研究科機械工学専攻 干113-8656 東京都文京区本郷, Dept. of Mech. Eng., Tokyo Univ., Bunkyo-ku, Tokyo, 113-8656

** 学生会員 東京大学大学院工学系研究科機械工学専攻 ₹113-8656 東京都文京区本郷, Graduate Student, Tokyo Univ., Bunkyo-ku, Tokyo, 113-8656

*** 東京大学大学院工学系研究科機械工学専攻 =113-8656 東京都文京区本郷, Dept. of Mech. Eng., Tokyo Univ., Bunkyo-ku, Tokyo, 113-8656
} 


$$
F(t)=1-\exp \left\{-\left(\frac{t}{\beta}\right)^{\alpha}\right\}
$$

$t$ は補修を行ってからの経過時間である。起動停止回数 が損傷に影響するため, 起動停止一回を単位時間に対応 付けた。 $\alpha$ は形状母数, $\beta$ は尺度母数であり, この二つ の母数を検查結果から推定した. 以後, 形状母数を $\alpha$, 尺度母数を $\beta$ と記述する. 式 (1) は時刻 $t$ までの間に疲 労き裂が発生する確率であるため, F $(t)$ を破損確率とし て, 破損率評価を要求されるリスクベースメンテナンス (RBM) に利用することが可能である。

\section{$2 \cdot 2$ ベイズ推定}

一般に検査記録から寿命分布母数を推定する際に，次 のような状況である場合が多い

(1) 既存のデータもしくは今後の検査データから機器 の寿命分布を推定する際に，十分な量のデータが 利用できない.

(2) 個別の機器のデータは存在しなくとも, 類似機器 に共通してあてはまるデータベースから，寿命分布 の推定に利用できる情報が得られる。あるいは，試 験データなどをもとにした設計時の寿命分布デー タが存在する。

このような状況の場合には, 純粋に客観的な統計処理 を行うよりも，母数の主観確率分布を検査データに基づ いて更新していくことで推定を行うべイズ推定が有効で あると考えられる。

以下ベイズ推定の実施方法を述べる。 $\boldsymbol{\theta}$ を推定を行う 母数のべクトル， $A$ を検査によって観察される事象とす るとき，観察事象によって更新された母数の事後分布は ベイズの定理（式 (2)）によって求められる。6),7),8)

$$
P(\boldsymbol{\theta} \mid A)=\frac{P(A \mid \boldsymbol{\theta}) P(\boldsymbol{\theta})}{\int_{\boldsymbol{\theta}} P(A \mid \boldsymbol{\theta}) P(\boldsymbol{\theta}) d \boldsymbol{\theta}}
$$

$P(A \mid \boldsymbol{\theta})$ は母数がある值 $\boldsymbol{\theta}$ をとるという条件のもとで, $A$ という事象が得られる条件付確率として与える。 ベイズ 推定は推定対象の母数 $\boldsymbol{\theta}$ が確率密度関数に従うばらつき を持つものとして扱い，事前分布 $P(\theta)$ を，得られた事象 $A$ の情報を取り入れた事後分布 $P(\boldsymbol{\theta} \mid A)$ に更新すること で推定を行う。従って, 類似機器に共通するデータベース から予測される分布を初期の事前分布としてべイズ推定 を開始し，以後は検査のたびごとに更新していくことに より，母数の推定精度を高めていくことが出来る。この 場合，事前分布が適切であれば，少ないデータから母数 推定を比較的精度良く行うことが出来る.

ベイズ推定により母数の区間推定を行う場合，通常の 統計学で用いられる信頼区間は用いず，確信区間を用い る.7), ${ }^{8)}$ 確信区間は，母数の事後分布の両端からある確率 の区間を切り取って残った，中央部の区間である。一方， 最尤法によって区間推定を行う場合には信頼区間を用い る。そこで本論文では，最尤法との比較を行うときには， 信頼区間をべイズ推定による確信区間と対応付けて検討 することとした.

本論文に打けるモデルでは事象 $A$ としては，前回の検
査から今回の検査までの期間内に，き裂が発生しなかっ た事象 (safe) とき裂が発生した事象 (failure) の二通りが

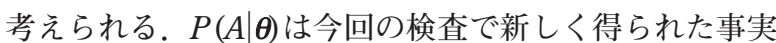
を反映したものであるため，前回の検査時点でき裂が発 生していないという条件付の確率を求めた。攵のため $P(A \mid \theta)$ としてき裂が発見されなかった場合は式 (3)，き 裂が発見された場合は式 (4)を用い, 複数の機器に対す る検査結果を得た場合には, 各機器 $i$ の $P_{i}(A / \theta)$ の積を もって $P(A \mid \theta)$ とした。

$$
\begin{aligned}
& P(\text { safe } \mid \alpha, \beta)=\exp \left(\left(\frac{t_{\text {last }}}{\beta}\right)^{\alpha}-\left(\frac{t_{\text {inspect }}}{\beta}\right)^{\alpha}\right) \\
& P(\text { failure } \mid \alpha, \beta)=1-\exp \left(\left(\frac{t_{\text {last }}}{\beta}\right)^{\alpha}-\left(\frac{t_{\text {inspect }}}{\beta}\right)^{\alpha}\right)
\end{aligned}
$$

ただし， $t_{\text {inspect }}$ は補修後，検査が行われるまでの経過時間 である． $t_{\text {last }}$ は前回の検査が行われるまでの時間であり， 今回が補修後初めての検査である場合には 0 である。

\section{$2 \cdot 3$ 初期の事前分布の設定}

ベイズ推定を行うにあたっては，母数に対する初期の 事前分布の設定は重要である。そこで本論文では，事前 分布の与え方とべイズ推定の有効性を系統的に調査した。 過去の経験に基づく情報，あるいは過去のデータの蓄積 などの情報が何らかの形で存在する場合と存在しない場 合とで分けて考えることとした。

疲労寿命分布の母数についての情報がデータベース等 から予測できる場合には，予測された分布データをもつ て初期の事前分布とすることが妥当である。このため初 期の事前分布を式 (5)のように二母数が互いに独立な対 数正規分布と仮定し， $\alpha$ と $\beta$ の様々な初期分布について 調査した

$$
\begin{aligned}
f_{\text {prior }}(\alpha, \beta)= & \frac{1}{\sqrt{2 \pi} \alpha \sigma_{\alpha}} \exp \left(-\frac{1}{2}\left(\frac{\ln \alpha-\ln M e_{\alpha}}{\sigma_{\alpha}}\right)^{2}\right) \\
& \times \frac{1}{\sqrt{2 \pi} \beta \sigma_{\beta}} \exp \left(-\frac{1}{2}\left(\frac{\ln \beta-\ln M e_{\beta}}{\sigma_{\beta}}\right)^{2}\right)
\end{aligned}
$$

$M e_{\alpha}, M e_{\beta}$ は事前分布に打ける $\alpha, \beta$ の中央值であり, $\sigma_{\alpha}$, $\sigma_{\beta}$ は事前分布における $\ln \alpha, \ln \beta$ の標準偏差である。 $\alpha$, $\beta$ ともに正の值しかとりえないため，自動的にこの条件 を満足する対数正規分布を採用した.

一方，初期の時点で，母数の分布について何の情報も 存在しない場合には，母数に関する情報を一切持たない 分布を事前分布として与えることでべイズ推定が行える. このような考え方のもとで与えられる事前分布を無情報 性事前分布 (Noninformative prior) という.8), 9) 最も単純 な無情報性事前分布として一様分布が用いられることが 多い。しかし，同一の分布形であっても，異なる形式の 式で定義されることがあり，この場合には母数の定義が 異なることになる，従って，ある定義で母数が一様分布 していても異なる定義では一様分布になるとは限らない. この場合，ある特定の值に高い確信の度合いを与えるこ とになりかねず，無情報性事前分布としては不適切であ る. 推定する分布が二母数ワイブル分布である場合には, 
これらの問題を生じない無情報性事前分布として, Sun ${ }^{9)}$ が式 (6)を誘導している.

$$
f_{\text {prior }}(\alpha, \beta) \propto \frac{1}{\alpha \beta}
$$

本論文では，このような無情報の状態から出発する場 合のベイズ推定についてもあわせて有効性を検討するこ ととした。

\section{$2 \cdot 4$ 破損確率 - MTBF ・故障率の推定}

検査計画を検討する際に, 重要な要素となるのは破損確 率, MTBF (Mean Time Between Failure)，故障率 (hazard rate) である. べイズ推定によって推定される $\alpha, \beta$ の分 布から, これらの量は以下の手順で求められる.

$\alpha, \beta$ が求まれば，時刻 $t$ までの破損確率は式 (1)で与 えられる。

MTBF は修理された機器が破損するまでの平均時間間 隔である.MTBF は新規に検査間隔を設定したり，現状 で用いている検査間隔の妥当性を評価する場合，重要と なる．従って，べイズ推定の効果を調査するための指標 として MTBF を採用する。疲労寿命が二母数ワイブル分 布に従う場合, MTBF は式 (7)より求められる。

$$
M T B F=\beta \Gamma\left(1+\frac{1}{\alpha}\right)
$$

ここで $\Gamma(x)$ はガンマ関数である.

故障率は時刻 $t$ まで正常に動作していた機器が引き続 く単位時間に故障を起こす割合であり，疲労寿命が二母 数ワイブル分布に従う場合, 時刻 $t$ に打ける故障率は 式 (8)で求められる.6)

$$
\lambda(t)=\frac{\alpha}{\beta}\left(\frac{t}{\beta}\right)^{\alpha-1}
$$

\section{$3 \cdot 1$ 使用した検査記録}

\section{3 検查データへの適用}

実機の検查データに対してベイズ推定を行い, ベイズ 推定の母数推定法としての有効性の検討を行った。対象 としたのはボイラ壁面に走る管に対し溶接された炉壁付 箱型構造物である。この構造物のコーナ部の溶接部では, 起動停止に伴う熱応力の変動によりき裂が発生する。こ の溶接部に対する熱疲労き裂検査記録を元に，き裂発生 寿命の推定を行った。検査記録は三回の検查実施時点に 打ける累積起動停止回数，および対象部位のき裂の有無 から成っており，詳細を Table I に示す。

\section{$3 \cdot 2$ 寿命分布母数の推定}

まず，事前にまったく情報が与えられていない場合に

\begin{tabular}{|c|c|c|c|c|}
\hline & $\begin{array}{l}\text { Number of } \\
\text { start and } \\
\text { stop }\end{array}$ & $\begin{array}{l}\text { Number of } \\
\text { inspected } \\
\text { equipment }\end{array}$ & $\begin{array}{l}\text { Number of } \\
\text { equipment } \\
\text { with } \\
\text { crack }\end{array}$ & $\begin{array}{l}\text { Number of } \\
\text { equipment } \\
\text { with } \\
\text { no crack }\end{array}$ \\
\hline 1st inspection & 225 & 128 & 128 & 0 \\
\hline 2nd inspection & 310 & 30 & 18 & 12 \\
\hline 3rd inspection & 331 & 96 & 18 & 78 \\
\hline
\end{tabular}
ついて検討した。 各検查終了時点において, 得られた検

Table I . Inspection records.
査データを用いて無情報性事前分布からのべイズ推定 （以降 Non-info.と略記する）を行った。また通常の統計 処理との比較を行うため, 最尤法 (MLM : Maximum Likelihood Method) による各検查終了時点における母 数推定をあわせて行った。推定の結果得られた $\alpha, \beta$ の 平均值および標準偏差を Table II に示す。検査一回目終 了時点では，あらゆる機器にき裂が検出されたため，最 尤法では最尤点が無限遠となる。一方 Non-info.では事後 分布が確率密度関数の条件を満たさない，従っていずれ についても有効な推定は行えない。検査二回目終了時点 では, 最尤法によって推定された $\alpha, \beta$ の標準偏差が極 めて大きいのに対し, Non-info.では特に $\beta$ の標準偏差が 小さく，狭い領域に母数を推定できる。検查三回目が終 了し, 利用できる検査データが増えた時点での推定結果 は，最尤法と Non-info.でほぼ一致しており，両者の顕著 な差異は無くなる。

次に母数の分布に関して, 予め類似機器のデータや破 壊試験などから情報が得られている場合を考え，式 (5) による事前分布を与えてベイズ推定を行った. Table II の検査データに対するべイズ推定から得られた $\alpha, \beta$ の 值に対して 0.5 倍程度から 2 倍程度の偏差を与えた 9 例 の事前分布を設定し，事前分布の与え方とべイズの定理 の有効性との関係を検証した。Table IIIに設定した 9 例 の事前分布の $M e_{\alpha}, M e_{\beta}, \sigma_{\alpha}, \sigma_{\beta}$ を示し, Table IVに心゙ イズ推定結果を示す。

Table II に示した最尤法，およびNon-info.の結果と比 較すると, Table IVのすべてのケースに打いて，利用で きる検査データが少ない段階から狭い範囲で母数推定が 可能である. 検査一回目終了時点では $M e_{\alpha}, M e_{\beta}$ によっ て推定結果は大きく異なる。検査二回目終了時点では利 用できる検査データが増えた結果，すべてのケースで $\beta$ の推定値に大きな差異は無いが， $\alpha$ の推定值は $M e_{\alpha}$ に依 存する。検査三回目ではさらに十分な検査データが利用 可能となり，すべてのケースにおいて， $\alpha$ と $\beta$ のいずれ

Table II . Results of MLM and Bayesian inference with non-informative prior estimated by inspection data

\begin{tabular}{|l|l|r|r|r|}
\hline & & 1st & 2nd & 3rd \\
\hline \multirow{3}{*}{ MLM } & $\alpha$ & $(\infty)$ & $3.35 \pm 542.02$ & $2.63 \pm 0.31$ \\
\cline { 2 - 5 } & $\beta$ & $(0)$ & $87.2 \pm 367.8$ & $130.9 \pm 6.0$ \\
\hline \multirow{2}{*}{$\begin{array}{l}\text { Non-info. } \\
\text { Bayesian }\end{array}$} & $\alpha$ & $(0)$ & $10.90 \pm 32.27$ & $2.63 \pm 0.32$ \\
\cline { 2 - 5 } & $\beta$ & $(0)$ & $86.3 \pm 7.4$ & $130.4 \pm 6.1$ \\
\hline
\end{tabular}

Table III . Prior distributions setting for weibull parameters.

\begin{tabular}{|l|r|r|r|r|r|r|r|r|r|}
\hline & $\begin{array}{c}\text { Case } \\
1\end{array}$ & \multicolumn{1}{c}{ Case } & Case & \multicolumn{1}{c|}{$\begin{array}{c}\text { Case } \\
4\end{array}$} & $\begin{array}{c}\text { Case } \\
5\end{array}$ & $\begin{array}{c}\text { Case } \\
6\end{array}$ & $\begin{array}{c}\text { Case } \\
7\end{array}$ & $\begin{array}{c}\text { Case } \\
8\end{array}$ & $\begin{array}{c}\text { Case } \\
9\end{array}$ \\
\hline$M e_{\alpha}$ & 5 & 5 & 5 & 2.6 & 2.6 & 2.6 & 1.5 & 1.5 & 1.5 \\
\hline$\sigma_{\alpha}$ & 0.5 & 0.5 & 0.5 & 0.5 & 0.5 & 0.5 & 0.5 & 0.5 & 0.5 \\
\hline$M e_{\beta}$ & 250 & 130 & 60 & 250 & 130 & 60 & 250 & 130 & 60 \\
\hline$\sigma_{\beta}$ & 0.5 & 0.5 & 0.5 & 0.5 & 0.5 & 0.5 & 0.5 & 0.5 & 0.5 \\
\hline
\end{tabular}


Table IV. Results of Bayesian inference with 9 case priors estimated by inspection data.

\begin{tabular}{|l|l|r|r|r|}
\hline & & $1 \mathrm{st}$ & $2 \mathrm{nd}$ & 3rd \\
\hline Case1 & $\alpha$ & $6.81 \pm 3.25$ & $4.57 \pm 2.27$ & $2.73 \pm 0.32$ \\
\cline { 2 - 5 } & $\beta$ & $130.6 \pm 30.6$ & $89.1 \pm 6.4$ & $131.5 \pm 6.0$ \\
\hline \multirow{3}{*}{ Case2 } & $\alpha$ & $6.22 \pm 3.15$ & $4.64 \pm 2.35$ & $2.73 \pm 0.32$ \\
\cline { 2 - 5 } & $\beta$ & $104.9 \pm 33.9$ & $88.0 \pm 6.0$ & $130.7 \pm 6.0$ \\
\hline \multirow{3}{*}{ Case3 } & $\alpha$ & $5.75 \pm 3.00$ & $4.63 \pm 2.32$ & $2.72 \pm 0.32$ \\
\cline { 2 - 5 } & $\beta$ & $64.5 \pm 29.6$ & $86.7 \pm 5.8$ & $130.0 \pm 5.9$ \\
\hline Case4 & $\alpha$ & $4.16 \pm 1.83$ & $2.97 \pm 1.12$ & $2.64 \pm 0.31$ \\
\cline { 2 - 5 } & $\beta$ & $114.3 \pm 28.2$ & $90.2 \pm 8.0$ & $131.3 \pm 6.0$ \\
\hline Case5 & $\alpha$ & $3.61 \pm 1.65$ & $2.96 \pm 1.16$ & $2.63 \pm 0.31$ \\
\cline { 2 - 5 } & $\beta$ & $91.5 \pm 29.2$ & $88.1 \pm 8.0$ & $130.6 \pm 6.0$ \\
\hline Case6 & $\alpha$ & $3.20 \pm 1.61$ & $2.95 \pm 1.24$ & $2.62 \pm 0.31$ \\
\cline { 2 - 5 } & $\beta$ & $59.2 \pm 25.6$ & $85.9 \pm 7.8$ & $129.7 \pm 6.1$ \\
\hline Case7 & $\alpha$ & $3.00 \pm 1.22$ & $2.40 \pm 0.73$ & $2.56 \pm 0.30$ \\
\cline { 2 - 5 } & $\beta$ & $101.2 \pm 26.1$ & $89.4 \pm 9.0$ & $131.2 \pm 6.1$ \\
\hline Case8 & $\alpha$ & $2.52 \pm 1.05$ & $2.37 \pm 0.74$ & $2.55 \pm 0.30$ \\
\cline { 2 - 5 } & $\beta$ & $80.4 \pm 25.8$ & $87.2 \pm 9.0$ & $130.4 \pm 6.1$ \\
\hline Case9 & $\alpha$ & $2.09 \pm 0.90$ & $2.27 \pm 0.75$ & $2.55 \pm 0.31$ \\
\cline { 2 - 5 } & $\beta$ & $53.6 \pm 22.0$ & $83.9 \pm 9.5$ & $129.5 \pm 6.1$ \\
\hline
\end{tabular}

についても，推定結果は最尤法打よび Non-info.の結果と ほぼ一致する。またすべてのケースにおいて利用できる 検査データが増えることで， $\alpha, \beta$ の分散は小さくなるこ とがわかる

\section{$3 \cdot 3 \mathrm{MTBF}$ と故障率}

検査一回目の時点で補修され，検査二回目および検査 三回目で，き裂が確認されなかった機器に対し，ベイズ 推定によって故障率を推定した。Fig. 1 に，推定した故 障率の $90 \%$ 確信区間の，時刻に対する推移を示す。事前 分布は, Table II からの推測值を用いている Case 5 を用 いた. 起動停止回数 310 回，331 回において新しい検査 結果を得ることで，母数の分布が更新されて母数の確信 区間が狭まる。この結果，故障率推定の不確定性が小さ くなることがわかる

Fig. 2 は最尤法, Non-info., そして適切な事前分布を 想定した Case 5 の事前分布によるべイズ推定の三つの 手法から推定される MTBF の 90\%確信区間を示したも のである. Non-info.は，最尤法と比較して，利用できる

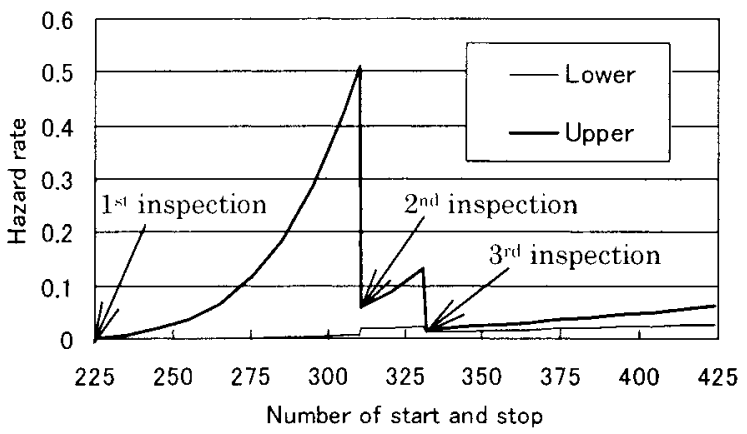

Fig. 1. Lower and upper bounds of $90 \%$ credible interval for hazard rate calculated using Bayesian inference with Case 5 prior estimated by inspection data.

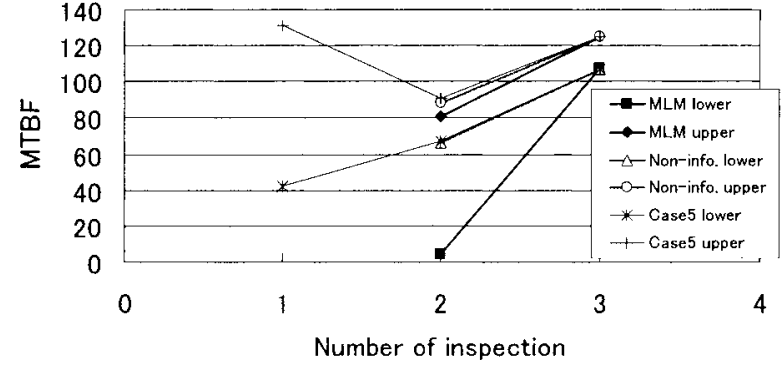

Fig. 2. Lower and upper bounds of $90 \%$ credible interval for MTBF calculated using MLM and Bayesian inference with non-informative prior and Case 5 prior estimated by inspection data.

検査データが少ない時点からより狭い範囲にMTBF を推 定できる．さらに，Case 5 のように適切に事前分布を与 えれば，Non-info.では推定できない検査一回目において も推定が可能である。ただし十分な検査記録がある場合 にはどの推定手法でも結果はほぼ一致している。

\section{4 シミュレーションによる検討}

\section{$4 \cdot 1$ シミュレーション法}

事前分布の影響を調べるため，正解とする母数を設定 し，事前分布の正解に対する偏差が，ベイズ推定の結果 にどのように影響するかをシミュレーションにより系統 的に明らかにした。母集団として第 3 章の実機データか ら推測された $\alpha=2.6, \beta=130$ のワイブル分布を仮定し た. 検査対象機器数は 10 とした. 起動停止回数 30 回ご とに検査が行われ，き裂発生寿命に至った機器は見落と されることなく発見されるとした，検査で，き裂が確認 された部位は，新品に交換されるものとした。

以上の条件のもとで 20 例の仮想的な検査データを作 成し，各検査終了時に，この仮想検査データを用いて， 最尤法による推定およびべイズ推定を行った。結果とし て，20 例の仮想検査記録による推定結果の平均值を求め た. ベイズ推定における事前分布は無情報性事前分布の ほか，Table IIIに示した 9 ケースを設定し比較すること で有効性を検討した。

\section{$4 \cdot 2$ 寿命分布母数に対する推定}

推定值の妥当性を示す指標として, 相対誤差 $d_{p o s t}$ を 式 (9)のように定義した。 $\alpha_{\text {post }}, \beta_{\text {post }}$ は事後分布で同時確 率密度が最も高くなる位置の $\alpha, \beta$ である。 $\alpha_{\text {true }}, \beta_{\text {true }}$ は $\alpha, \beta$ の真值であり，それぞれ 2.6，130である.

$$
d_{\text {post }}=\sqrt{\left(\frac{\alpha_{\text {post }}}{\alpha_{\text {true }}}-1\right)^{2}+\left(\frac{\beta_{\text {post }}}{\beta_{\text {true }}}-1\right)^{2}}
$$

検査三回目，六回目，九回目終了時点での最尤法， Non-info., Case 1〜9の事前分布を与えた場合の $\alpha_{\text {post }}$, $\beta_{\text {post }}$ および $d_{\text {post }}$ を Table Vに示す. Non-info.の $d_{\text {post }}$ は検 查回数に関係なく最尤法の $d_{p o s t}$ より小さく, 特に検査回 数が少ないほど最尤法と Non-info.の差は顕著である。こ のように利用可能なデータが少ない際のベイズ推定によ る母数推定が有効であることが確認できる.

検査三回目終了時点の Case $1 \sim 9 の d_{p o s t}$ は最尤法よ 
Table V. Results of MLM and Bayesian inference with noninformative prior and 9 case priors calculated by simulated data.

\begin{tabular}{|l|c|c|c|c|c|c|c|c|c|}
\hline & \multicolumn{3}{|c|}{ 3rd } & \multicolumn{3}{c|}{6 th } & \multicolumn{3}{c|}{9 th } \\
\cline { 2 - 11 } & $\alpha_{\text {post }}$ & $\beta_{\text {post }}$ & $d_{\text {post }}$ & $\alpha_{\text {post }}$ & $\beta_{\text {post }}$ & $d_{\text {post }}$ & $\alpha_{\text {post }}$ & $\beta_{\text {post }}$ & $d_{\text {post }}$ \\
\hline MLM & 22.5 & 135.2 & 14.3 & 3.35 & 124.9 & 0.290 & 2.93 & 125.5 & 0.131 \\
\hline $\begin{array}{l}\text { Non- } \\
\text { info. }\end{array}$ & 3.44 & 124.4 & 0.326 & 3.14 & 123.2 & 0.214 & 2.82 & 124.1 & 0.095 \\
\hline Case1 & 3.53 & 124.5 & 0.358 & 3.41 & 127.0 & 0.312 & 3.03 & 127.3 & 0.169 \\
\hline Case2 & 3.90 & 112.3 & 0.518 & 3.40 & 123.6 & 0.313 & 3.02 & 124.9 & 0.166 \\
\hline Case3 & 4.18 & 104.7 & 0.639 & 3.38 & 120.1 & 0.308 & 3.00 & 122.3 & 0.163 \\
\hline Case4 & 2.36 & 146.1 & 0.154 & 2.99 & 127.4 & 0.150 & 2.78 & 126.8 & 0.074 \\
\hline Case5 & 2.69 & 122.9 & 0.066 & 2.99 & 123.2 & 0.158 & 2.78 & 124.2 & 0.084 \\
\hline Case6 & 2.93 & 109.6 & 0.202 & 2.97 & 118.8 & 0.166 & 2.76 & 121.2 & 0.092 \\
\hline Case7 & 1.70 & 170.6 & 0.466 & 2.63 & 128.5 & 0.018 & 2.59 & 126.7 & 0.026 \\
\hline Case8 & 1.97 & 134.4 & 0.246 & 2.65 & 123.1 & 0.056 & 2.58 & 123.6 & 0.050 \\
\hline Case9 & 2.15 & 114.1 & 0.213 & 2.63 & 117.7 & 0.096 & 2.56 & 120.2 & 0.077 \\
\hline
\end{tabular}

り小さく，Me を過大に見積もった Case $1 \sim 3, M e_{\alpha}$ を過小かつ $M e_{\beta}$ を過大に見積もった Case 7 を除いて Non-info.より小さい。 また，検査六回目終了時点に扎い ては, Case $4 \sim 9$ の $d_{\text {post }}$ は最尤法, Non-info.よりも小 さいが，Me を過大に見積もった Case $1 \sim 3$ は最尤 法・Non-info.より大きい．検査九回目終了時点の結果 は検査六回目終了時点と同様の傾向だが，推定手法や事 前分布による $d_{p o s t}$ の差は小さい. $d_{p o s t}$ の值は全般的に事 前分布の $M e_{\alpha}$ に強く依存しており, 特に利用可能な検査 記録が多い場合に $M e_{\alpha}$ の影響が大きい.ここから $\beta$ と比 較して $\alpha$ の更新が遅いことがわかる.

\section{$4 \cdot 3$ MTBF と故障率}

Fig. 3 は最尤法, Non-info., そして適切な事前分布を 想定した Case 5 の事前分布によるべイズ推定の三手法に よって推定される MTBF90\%確信区間を示したものであ る. Fig. 4 は事前分布の $M e_{\alpha}$ の影響を調べるため, Case $2 ， 5 ， 8$ の事前分布に対してべイズ推定より求められた MTBF90\% 確信区間を示したものである.Fig. 5 は事前

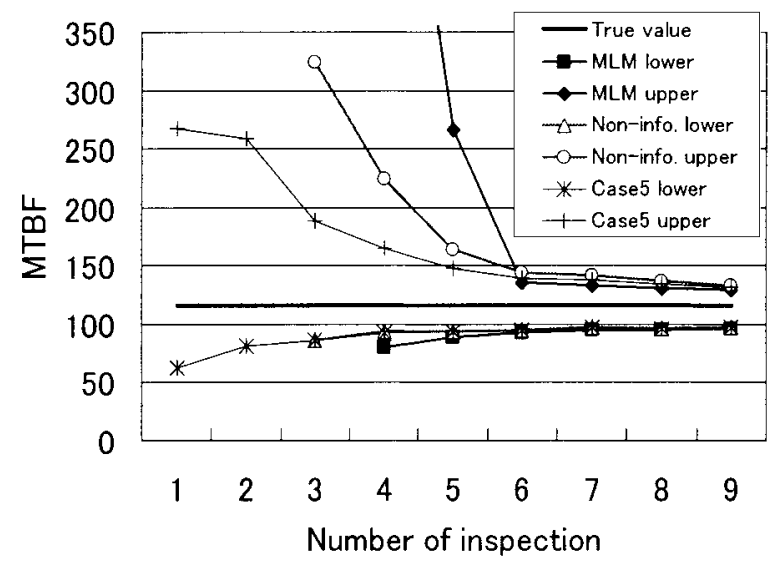

Fig. 3. Lower and upper bounds of $90 \%$ credible intervals of MTBF calculated using MLM and Bayesian inference with non-informative prior and Case 5 prior estimated by simulated data.

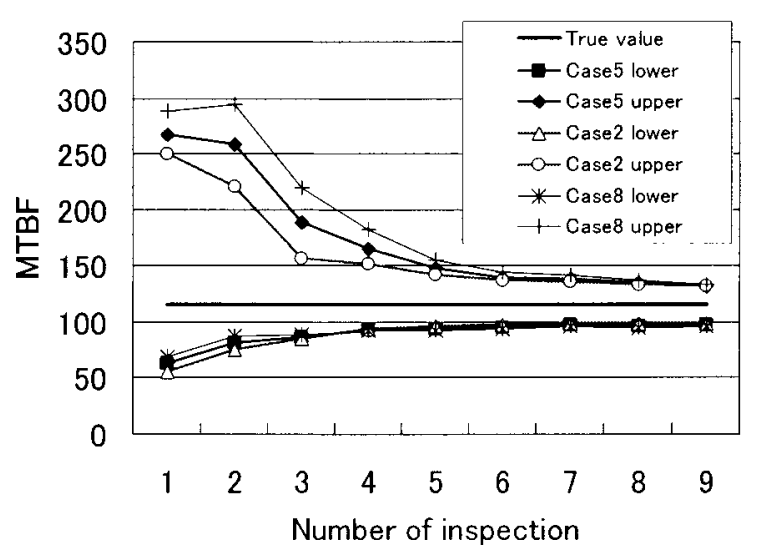

Fig. 4. Lower and upper bounds of $90 \%$ credible intervals for MTBF calculated using Bayesian inference with Case 2, Case 5 , and Case 8 prior estimated by simulated data.

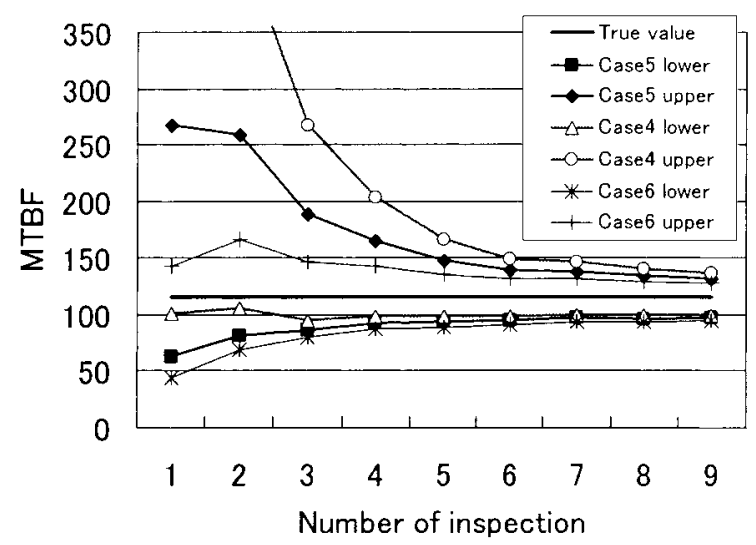

Fig. 5. Lower and upper bounds of $90 \%$ credible intervals for MTBF calculated using Bayesian inference with Case 4, Case 5, and Case 6 prior estimated by simulated data.

分布の $M e_{\beta}$ の影響を調べるため, Case 4, 5, 6 の事前 分布に対してべイズ推定より求められた MTBF90\% 確信 区間を示したものである。

Non-info.による MTBF 推定は，利用できる検査デー タが少ない場合には，最尤法と比較して推定の確信区間 が狭く有利である．ただし検査データが豊富にある場合 には最尤法と比較して大きな差は見られない。

検查回数が少なく，き裂がまったく検出されない場合 には，Non-info.では MTBF の推定が困難である。しか し，たとえこのような場合であっても，破壊試験や類似 機器のデータなどから式 (5)を利用して適切に事前分布 を与えることにより，MTBF の推定が可能であり，推定 される MTBF の確信区間も狭い。このとき事前分布の $M e_{\alpha}$ を過大もしくは過小評価しても MTBF の推定結果に 生じる䛊差は大きくないが, $M e_{\beta}$ を過大評価すると特に 検査記録が少ない段階で推定される MTBF の確信区間 が大きくずれてしまう。

機器の故障率 $90 \%$ 確信区間上界の経過時間による変動 について, Fig. 6, Fig. 7 に示す. Fig. 6 は $M e_{\alpha}$ の影響 を調べるため，Case 2，5，8の結果を四示している. 


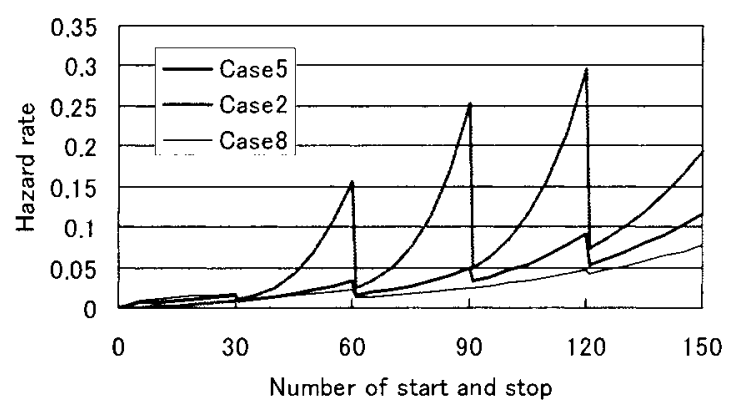

Fig. 6. Upper bounds of $90 \%$ credible interval for hazard rate calculated using Bayesian inference with Case 2, Case 5 , and Case 8 prior estimated by simulated data.

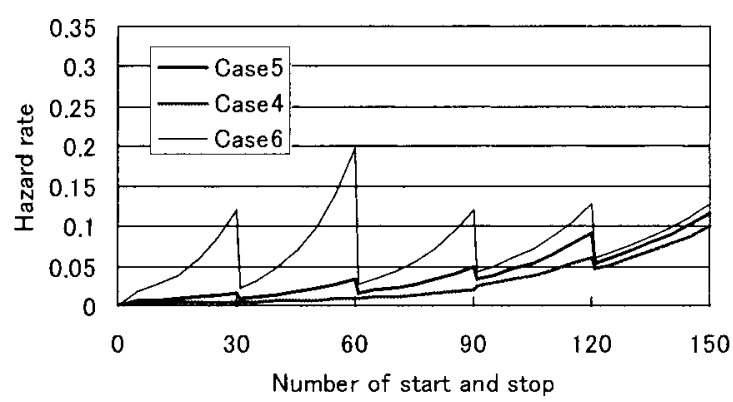

Fig. 7. Upper bounds of $90 \%$ credible interval for hazard rate calculated using Bayesian inference with Case 4, Case 5, and Case 6 prior estimated by simulated data.

Fig. 7 は $M e_{\beta}$ の影響を調べるため, Case 4, 5, 6 の結 果を図示している。事前分布の $M e_{\beta}$ の過大，過小評価の 故障率推定結果への影響は起動停止回数 30 回, 60 回, 90 回, 120 回と検査回数の増加につれて小さくなるが, $M e_{\alpha}$ の過大・過小評価の故障率推定結果への影響は検査 が行われてもあまり小さくならない.

\section{5 考察}

Table Vの Case $1 \sim 3$ のように, 事前分布の $M e_{\alpha}$ を 正解值より大きく設定した場合には，検査回数が増えて も $\alpha$ の誤差はあまり減少しないことから, $M e_{\alpha}$ の事前分 布の設定がその後のベイズ推定に大きな影響を及ぼすこ とがわかる.このため, 故障率のように $\alpha$ の影響が大き い值のべイズ推定にあたって，根拠のない $M e_{\alpha}$ の設定は 避けなければならない。この意味で $M e_{\alpha}$ に関する情報が 無いときには，特定の $M e_{\alpha}$ を設定しない，無情報性事前 分布を利用するべきである。

一方, MTBF の推定值については，事前分布の $M e_{\alpha}$ の影響は小さく, $M e_{\beta}$ の影響が大きい傾向があることが Fig. 4 と Fig. 5 の比較から分かる.これは式 (7)におい て $\alpha \geqq 1$ であれば式 (10)が成り立ち, $\alpha$ が MTBF に与 える影響が小さいことによるものと考えられる， $\alpha \geqq 1$ であることは時刻とともに故障率が増大することを意味 し，これは疲労寿命の場合に該当する。

$$
0.88<\Gamma\left(1+\frac{1}{\alpha}\right) \leq 1
$$

このため利用できる検査データが少ない場合には, $M e_{\beta}$ が適切に評価されていれば，式 (6)によって事前分布か らべイズ推定を行うことでMTBF の確信区間を狭くする ことができる. $M e_{\beta}$ の評価が困難である場合, 特定の $M e_{\beta}$ を設定しない，無情報性事前分布を用いるべきである. これにより，最尤法による推定が困難であるような，検査 回数が少ない時点から有効な MTBF 推定が行える.ただ し利用可能な検査記録が十分に多い場合には，べイズ推 定の優位性は失われ，最尤法による推定で十分である.

\section{6 結言}

疲労き裂検査データから, ベイズ推定によって, 疲労 き裂発生寿命を推定する方法を検討した，また，実機検 査データ，および乱数による仮想的な検查記録を用いて 最尤法打よびベイズ推定により疲労き裂寿命を推定し， ベイズ推定の最尤法に対する有効性とその範囲を調查し た. 以下に本研究で得られた結論をまとめる。

(1) 疲労き裂発生寿命を二母数ワイブル分布と仮定 し，熱疲労き裂検查記録からべイズ推定を行うことで寿 命分布の母数推定が行え, 同時にMTBF および故障率 を求めることができた，検查記録が十分に存在する場合 は最尤法を用いることでも同様の推定を行うことがで きる。

（2）予め母数に対する情報が特に無い場合には無情報 性事前分布からべイズ推定を行うことで，最尤法での推 定が難しい，検査回数が少ない状態からでも有効に推定 を行うことができる。

（3）べイズ推定を行う際に，適切に事前分布を与える ことができれば，無情報性事前分布では有効に推定が行 えないケースであっても，寿命を狭い確信区間で推定す ることが可能になる.

（4） MTBF を推定する場合は尺度母数に, 故障率推 定の際には形状母数に不適切な值を事前分布として与え ると推定誤差が大きくなる。これらの母数に関する明確 な情報が無い場合には無情報性事前分布を用いるべきで ある。

（5）検査記録が十分に存在する場合にはベイズ推定の 優位性は失われ，最尤法による推定が適切である。

\section{参 考 文 献}

1）酒井信介，金属学会誌，66，1170（2002）.

2）小林英男, 日本機械学会誌, 106, 846 (2003).

3) API Publication 581, Risk-Based Inspection Base Resource Document (2000).

4）市川昌弘，“構造信頼性”，p.160（1988）海文堂.

5) J. M. Bernardo, A. F. M. Smith, "Bayesian theory", p.241 (1994) John Wiley.

6）市川昌弘, “信頼性工学”, p.8（1990）裳華房.

7 ) 渡辺 洋, “ベイズ統計学入門”, p.14（1999）福村出版.

8 ) B. P. Carlin and T. A. Louis, "Bayes and empirical bayes methods for data analysis second edition”, p.17 (2000) Chapman \& Hall/CRC.

9 ) D. Sun, J. Statistical Planning and Inference, 61, 319 (1997). 